\title{
Financial and Accounting Approaches in Lease Appraisal
}

\author{
Alessandro Migliavacca ${ }^{1}$, Mariacristina Uberti ${ }^{1}$, Christian Rainero $^{1} \&$ Luisa Tibiletti ${ }^{1}$ \\ ${ }^{1}$ Department of Management, School of Management and Economics, University of Torino, Italy \\ Correspondence: Mariacristina Uberti, Department of Management, School of Management and Economics, \\ University of Torino, Italy. E-mail: mariacristina.uberti@unito.it
}

Received: February 27, 2018

Accepted: March 28, 2018

Online Published: March 30, 2018

doi:10.5539/ijbm.v13n5p13

URL: https://doi.org/10.5539/ijbm.v13n5p13

\begin{abstract}
The determination of the residual debt at a given date of a lease agreement, when it occurs the case of insolvency or continuous arrears (i.e. an early termination, before the maturity of the lease plan), is often regulated by the contract, which fixes penalties and some kind of impairment reimbursement. Both the lessor and the lessee are required to calculate separately for the amount of the outstanding debt and the sum of the impairment reimbursement and of the penalties. In this paper, the authors propose a model for a precise quantification of the residual debt, the damage impairment and the penalty shares based on three rates: the contractual rate, the implicit internal rate(s) of return and the market prime rate. This model is consistent with both finance and accounting perspectives. The developed methodology can also be proven capable to detect early any usury behavior, when it is given a threshold by the law or when it can be inferred from the market, therefore improving decision making and the forecasting of actual costs of the agreement.
\end{abstract}

Keywords: lease contract, leasing, early termination, accounting principles, financial approach

\section{Introduction}

The Italian law lacks in an explicit regulation about lease agreement so many different events during the lifetime of these contracts are inferred by analogy with similar regulated contracts. The evaluation of the outstanding debt at a given epoch during the contract lifetime may generate controversies, in certain circumstances, because of the non-compliance of contract clauses among some legal and financial calculus aspects.

It is then interesting to examine both the complexity of the matter and the difficulty to face some critical aspects that emerge from the analysis of some actual cases of contracts, in particular when the customer credit must be evaluated because of the early termination during the life of an installment contract (Van Horne \& Wachowicz, 2008; Van Horne James, 2002). Moreover, the variability amongst the evaluations and the time span lying between the account recording and the actual debt determination in a trial, may conduct to a consistent gap between what it is disclosed in the financial statement and what it is due after the judicial pronunciation (Carretta \& Nicolini, 2004; Hull, 1982; Lease, McConnell, \& Schallheim, 1990; McConnell \& Schallheim, 1983; Nicolini, 2004; Slovin, Sushka, \& Polonchek, 1990).

One of the most debated and interesting events involves the evaluation of the outstanding debt at a given epoch during the contract lifetime in the Italian legislative framework. This paper builds upon a Peccati's (1986) model which makes the proposition to decompose the debt into three shares (outstanding debt, damages and penalty). Migliavacca, Uberti, Puddu, and Tibiletti, (2015) have recently highlighted how this proposed decomposition settlement provides a simple and transparent procedure that is compatible with both finance and accounting perspectives.

Moreover, Migliavacca, Puddu, Tibiletti, and Uberti (2017) have extended the previous results showing how the calculation and assessment of the components of the debt turn out to be fruitful in two different contexts: the owed in the course of a lawsuit; the financial accounting and reporting according to some accounting methodologies (In-balance-sheet, such as IFRS, and off-balance-sheet, such as Italian GAAP; IFRS (IAS 17); OIC (2014a, 2014b). While, in Migliavacca et al. (2017, 2016), given the capability of the proposed approach to provide a decomposition of the credit in a transparent and handle way to use, from both a financial and an accounting viewpoint, actual cases are studied within a multi-disciplinary framework.

Since this approach is proven to be particularly consistent with both of the main accounting methodologies, because those principles require the best quantification of the two (or three, if the damage is split into penalties 
and impairment) components, in this paper the deepening of this study will be a matter of singular interest by the analysis of several actual cases.

We examined both the complexity of the matter and the difficulty to face some critical aspects that emerge from the analysis of some contracts, in particular when the customer credit must be evaluated because of the early termination during the life of an installment contract.

The remainder of the paper is organized as follows. In the second paragraph, we introduce the basic notation and the financial model, in the third paragraph the main results are illustrated and the last concludes.

\section{Financial Approach and Accounting Implications}

\subsection{A Financial Approach for the Outstanding Debt Calculation}

Following Migliavacca et al. $(2016,2017)$, let $A$ be the price of the asset referring to a lease agreement and let $R_{s}$ be the installments due to the lessor by the lessee at maturities $\mathrm{t}_{\mathrm{s}}$, where $\mathrm{t}_{0} \leq \mathrm{t}_{\mathrm{s}} \leq \mathrm{t}_{\mathrm{n}}=\mathrm{T}, 0 \leq \mathrm{s} \leq \mathrm{n}$ with $\mathrm{t}_{0}$ and $T$ denote the contract date and the final maturity date, respectively ${ }^{\mathrm{i}}$.

If $i$ is the contractual rate (i.e. the Internal Rate of Return, IRR) implicit in the lease and chosen by the lessor, then the price $A$ is typically determined as the total present value of installments $R_{s}, t_{0} \leq t_{s} \leq t_{n}=T$, at contract date $\mathrm{t}_{0}$ :

$$
A=\sum_{s=0}^{n} R_{s} \cdot(1+i)^{-\left(t_{s}-t_{k}\right)}
$$

In the presence of an early termination of a lease agreement at maturity $t_{k}$ of the first not paid installment $R_{k}$ by the lessee, before the final maturity date $T$, at a given epoch $t_{k}$ during the contract lifetime the evaluation of the payments $R_{s}$ still due to the lessor at maturities $t_{s}$ is given by the present value $V(k)$

$$
V(k)=\sum_{s=k}^{n} R_{s} \cdot(1+k)^{-\left(t_{s}-t_{k}\right)}
$$

at the evaluation rate $k$, where $t_{k} \leq t_{s} \leq t_{n}=T, k \leq s \leq n$.

Therefore, the evaluation of the outstanding debt at a given epoch $t_{k}$ is the present value $V(i)$ at the IRR $i$ in equation (1).

As well known, the contractual clauses of a lease agreement provide the calculation of the present value $V(j)$ at a rate of resolution $j$ in equation (1), since $V(j)$ should include the components of credit relating to:

(i) capital outstanding: equal to the actual value of the debt for the remaining installments;

(ii) impairment reimbursement: a debt (or a provision) $L$;

(iii) damage: penalties $P$.

Referring to Peccati's (1986) model, the lump-sum credit $V(j)$ can be split into three components (debt, damages and penalty) by using the contractual IIR $i$ as well as the most common discount rates involved in the financial markets.

Since the contractual rate $i$ is usually bigger than the rate of resolution $j$, then the outstanding debt $V(i)$ is less than the lump-sum credit $V(j)$ requested by the lessor for the early termination of the contract.

Therefore the difference $V(j)-V(i)$ can be interpreted as the sum of the amounts of compensation for loss $L$ for the early termination of the contract and penalty $P$. Then the lump-sum credit $V(j)$ turns out to be:

$$
V(j)=V(i)+L+P
$$

i.e., the sum of the three components: outstanding debt $V(i)$, the impairment compensation $L$ and the penalty $P$.

Indeed, the compensation for loss $L$ can be quantified as the amount to be paid at maturity $t_{k}$ and it may consider as the difference between the expected profit and the realized profit by the lessor. Moreover, the expected profit can be evaluated as the present value of the not paid installments at the passive reference rate, i.e. the prime rate $p$ (about the importance of the choice of the rate see, e.g., Van Horne 2002 and Van Horne and Wachowicz 2008).

If, as it is customary, we assume that the relations among financial rates are $j<p<i$, it follows $V(i)<$ $V(p)<V(j)$ and then that:

- $\quad$ the impairment compensation is

$$
L=V(p)-V(i)
$$


- $\quad$ and the penalty is

$$
P=V(j)-V(p)
$$

In this way, substituting equations (3) and (4) into the equation (2), the lump-sum credit can be re-written:

$$
V(j)=V(i)+[V(p)-V(i)]+[V(j)-V(p)]
$$

\subsection{Accounting approaches for credit decomposition}

The model discussed above also meets accounting purposes. At first, some discrepancies between different accounting methods/theories are to be discussed.

As aforementioned, if the contract ends before the maturity $T$, with not paid or not expired installments, the debt $V(j)$ of the equation (2) can be broken down into two components:

- a debt - $V(i)$ of the equation (2) - for the not paid and not expired installments (capital share);

- a debt (or a provision) for impairment - $L$ of the equation (3) - and penalties (damage) - $P$ of the equation

(4).

The evaluation method shown above is suitable for this intent.

According to the literature (Beattie, Goodacre, \& Thomson, 2006; Goodacre, 2003; Imhoff \& Thomas, 1988; McGregor, 1996; Wilkins \& Zimmer, 1983) (Wilkins and Zimmer, 1983, Beattie et al., 2006, Goodacre, 2003, Imhoff \& Thomas, 1988, McGregor, 1996), financial lease accounting can be pursued through two main methodologies: the former requires only a disclosure of the lease in the balance sheet footnotes (i.e. Italian Generally Accepted Accounting Principles - OIC 12) the latter demands the capitalization of the asset by the lessee (i.e. International Financial Reporting Standard - IAS 17). Both methodologies reflect symmetrical accounts in the lessor balance sheet.

In the following we discuss the impact of each methodology of the model.

\section{3 "Footnotes only" Accounting Approach}

According to this approach, both the asset and the debt are recorded in the footnotes and depreciated/amortized according to the debt amortization schedule, and the installments are recorded as operating costs. Whatever the termination date, no asset or debt are recorded in the financial statement, except from those referring to not pay installments.

Then, in case of termination before the maturity date, from the lessee point of view, the capital share debt is offset by a supervention that is reported in the profit and loss statement (OIC 12, §105. d) for the V(I) amount (plus VAT, where applicable).

If we consider the terminal value in the calculation of the $V(i)$, so that we actually acquire the property of the asset, the amount will be recorded as the cost of the asset, which will be depreciated according to the rules for the specific asset. If the terminal value is not considered, no asset will be recorded in the financial statement, because of the return to the lessor.

On an accrual basis, this comprehensive installment for termination is recorded in the profit and loss statement of the same year.

Moreover, in the absence of any judicial question, also the penalties and the damage are recorded as a debt.

Anyways, a question could be raised over the contractual clauses regulating the penalties. In this case, the judge can reduce the penalty, if its amount is greater than the fair profit that the lessor could expect from the normal execution of the contract. The penalty and the major impairment compensation are recorded as operating costs for the amounts L and P, which are calculated by the equations (4) and (5), respectively. Again, on an accrual basis, it must be recorded in the same year of the termination.

If there is the above-mentioned question on the penalties, the amount $\mathrm{P}$ must be recorded as a provision for legal risks, together with the judicial cost estimate (OIC 31, §60). This recording is to adhere to the prudence principle of financial reporting and compliance to an accrual basis of accounting - it maintains the cost/provision in the balance sheet of the termination year, even if the related cash flow will be in the next or several years later.

The records for the lessor are symmetrical in the first two cases. If there is a lawsuit for the (re)determination of the penalties, the record will be the same as if there is not; if the penalty will be reduced, an extraordinary item will be recorded in the payment (OIC 12, $\$ 51 . \mathrm{d})$. If there are any chances of losing the lawsuit, the lessor must record a provision for the legal costs (OIC 31, §60). 
This method, stated and regulated by the current OIC, will be modified (whilst some quibbles are still leading to some behavior uncertainty) starting from the financial statement 2016, because of a recent reform of Italian law, compliance to the Directive 2013/34/UE. This reform introduced a stronger substance-over-form principle that could bring leases accounting criteria to even out with the internationally accepted (and applied) methodology.

\section{4 "Capitalization of the asset" Approach}

The capitalization accounting approach for finance leases creates a little more concern in the case of contract termination before maturity. This is mainly due to the natural difference between the contract (financial) amortization schedule and the asset (operative) depreciation and its (potential) impairments.

Indeed, whilst "at commencement of the lease term, finance leases should be recorded as an asset and a liability at the lower of the fair value of the asset and the present value of the minimum lease payments (discounted at the interest rate implicit in the lease, if practicable, or else at the entity's incremental borrowing rate)", during the execution of the contract the value of the debt (and, in particular, its actualized value) and the value of the asset are unlikely to correspond for the lessor:

1. The asset is systematically depreciated through a predefined schedule, according to the specific accounting rules for the typology of the asset;

2. The debt is amortized according to the contract schedule (which is normally shorter compared to the economic life of the asset and includes a terminal value payment that actually transfers the property).

In contrast with the other methodology, at every termination date before the maturity we will have the following values: (i) the asset depreciated value, recorded in the balance sheet, and the depreciation charges, recorded on accrual basis on the financial statements of the previous years; (ii) the residual debt value, recorded in the balance sheet; (iii) several records for the interests paid on the installments, in the financial statements of each year of contract.

At the termination of the contract the lessee should pay a debt composed by the $\mathrm{V}(\mathrm{i}), \mathrm{L}$ and $\mathrm{P}$ values as aforementioned. So, unless the terminal value is taken into consideration and the property consequently transferred, the asset must be returned to the lessor.

This value has to compensate with the asset fair value (at the termination date) for the entire V(i) amount. The potential difference between the amounts is extinguished by cash payment if the asset value is minor compared with the debt amount or, on the contrary, recorded as a loss in the income statement. The amounts $\mathrm{L}$ and $\mathrm{P}$ amounts should be extinguished through a standard payment.

Also in this case, the $\mathrm{P}$ amount could be questioned before the competent court (depending on the State legislation and the contract clauses) and consequently recorded as a provision (Note 2).

The model expresses in a clear and transparent way which amounts are imputable to the debt, the damages and penalties and to the consequent recording values, e.g. losses.

\section{Discussion}

\subsection{A numeric Example}

Hereunder we make use of the following explanatory case. A financial leasing contract is composed of these clauses:

- Duration of the contract: 10 years. Date of the contract Jan. 1st, 2016

- First installment Dec. 31st, 2016. Postponed installments.

- Contractual interest rate: $5 \%$.

- First installment charge: 20,000

- Further installment charges: 9,000 (9 years)

- Terminal value: 15,000

It is clear that the minimum payments are equal to 116,000 and the Net Present Value of the installments is equal to $89,180.50$. Assuming a fair value of the asset of 85,000 , the Internal Rate of Return is equal to $6 \%$. The asset useful life is 15 years.

We assume also that the market prime rate is equal to $4,71 \%$ and the lump-sum termination rate is equal to $4 \%$. We can re-write the rates as follows:

- $\quad i=6 \%$ 
- $p=4,71 \%$

- $j=4 \%$

The financial plan of the contract is the following.

Table 1. Example financial plan - our adaptation from (Migliavacca et al. 2015)

\begin{tabular}{lllllll}
\hline Date & Asset & Depreciation & Debt & Installment & Capital & Interests \\
\hline $31 / 12 / 15$ & 85,000 & 0 & 85,000 & & 0 & 0 \\
$31 / 12 / 16$ & 79,333 & 5,667 & 70,099 & 20,000 & 14,901 & 5,099 \\
$31 / 12 / 17$ & 73,667 & 5,667 & 65,304 & 9,000 & 4,795 & 4,205 \\
$31 / 12 / 18$ & 68,000 & 5,667 & 60,221 & 9,000 & 5,083 & 3,917 \\
$31 / 12 / 19$ & 62,333 & 5,667 & 54,833 & 9,000 & 5,388 & 3,612 \\
$31 / 12 / 20$ & 56,667 & 5,667 & 49,122 & 9,000 & 5,711 & 3,289 \\
$31 / 12 / 21$ & 51,000 & 5,667 & 43,069 & 9,000 & 6,053 & 2,947 \\
$31 / 12 / 22$ & 45,333 & 5,667 & 36,653 & 9,000 & 6,416 & 2,584 \\
$31 / 12 / 23$ & 39,667 & 5,667 & 29,851 & 9,000 & 6,801 & 2,199 \\
$31 / 12 / 24$ & 34,000 & 5,667 & 22,642 & 9,000 & 7,209 & 1,791 \\
$31 / 12 / 25$ & 28,333 & 5,667 & - & 24,000 & 22,642 & \\
$31 / 12 / 26$ & 22,667 & 5,667 & & & & \\
$31 / 12 / 27$ & 17,000 & 5,667 & & & & \\
$31 / 12 / 28$ & 11,333 & 5,667 & & & & \\
$31 / 12 / 29$ & 5,667 & 5,667 & & & & \\
$31 / 12 / 30$ & 0 & 5,667 & & & & \\
\hline
\end{tabular}

If we suppose that the early termination date on Dec. 31st, 2020, computing the previous model we obtain the following amounts.

Table 2. Decomposed outstanding debt - our adaptation from (Migliavacca, 2015)

\begin{tabular}{lll}
\hline & Amount & Net of Terminal Value \\
\hline Net value of the Asset & 56,667 & \\
Outstanding debt $V(i)$ & $54,833+3,289=58,122$ & $46,912.79$ \\
Market prime rate debt $V(p)$ & $60,196,19$ & $48,279.65$ \\
Termination rate debt $V(j)$ & $61,395,31$ & $49,066.40$ \\
Damage compensation $L$ & $2,073,75$ & $1,366.85$ \\
Penalty $P$ & $1,199,11$ & 786.76 \\
\hline
\end{tabular}

Considering the case of asset return to the lessor, under both the accounting methodologies, we record a passive supervention $(1,366.85+786.76)$ offset by a debt $(2,153.61)$. If the Penalty is questioned, a provision for the risk will be recorded instead of the debt for the $P$ amount (786.76), while the $L$ amount remains fixed, because calculated with a market rate.

Under the capitalization methodology, we have also to close both the outstanding debt $(54,833)$ and the asset $(56,667)$ accounts, which difference generates a loss that has to be recorded as a supervention. Moreover, the interests for the year $(3,289)$ have to be liquidated and recorded consequently.

Considering the case of asset retaining from the lessee, the outstanding debt will not be compensated by the asset value. Thus, under the "footnotes only" accounting methodology, the asset will be recorded at the value of the remaining capital shares $(58,122)$ which will be depreciated considering a remaining useful life of ten years, and we will record slightly higher damage compensation $(2,073.75)$ and penalty $(1,199.11)$.

Under the capitalization methodology, the asset value will not change and the debt will be increased by the damage compensation and penalties.

Under both methodologies, the penalties can be questioned and it will be recorded in offset to a provision for the risk in the trial. 


\subsection{Implications of the Components of the Lease on Rate Fluctuation}

By using the discussed methodology, it is possible to examine how the different rates vary in relation to the different components of the equation.

In fact, by calculating all the different rates ( $\mathrm{j}, k, p$, with $i=\mathrm{IRR})$, it is possible to argue that all of the rates, all of the contract clauses are related with the effective/actual interest rate in several ways

1. If the good is returned to the lessor, the effective rate tends to be reduced; if the good is not returned, so that the terminal value is considered to be into the calculation, the rate tends to increase;

2. The presence of pre-amortisement leads to greater actual rates of the financial reimbursement

3. The presence of expenses, or arrears rates, or other costs, increase the actual rate;

4. The sooner the lessee stops to pay, the higher the actual rate will be,

5. The larger the difference between the rates of the calculation, the greater will be the amplification of the previous effects

These features could lead also to contingent usury situations, depending on the rules in force for the determination of the usury rates.

An expansion of the model can generalize those effects in order to achieve the comprehension of the relation between the elements and identifying other elements that can make the lessee raise questions on the fairness of the reimbursement and of the financial plan altogether.

\section{Conclusion}

The determination of the residual debt at a given date of a lease agreement, when it occurs the case of insolvency or continuous arrears (i.e. an early termination, before the maturity of the lease plan), is often regulated by the contract, which fixes penalties and some kind of impairment reimbursement. In those agreements, most of the issues arising from non-compliance to contract clauses imply to focus both legal and financial calculus aspects. This may generate controversies that, in certain circumstances, need for the evaluation of the outstanding debt at a given time before the maturity date.

It is then interesting to examine both the complexity of the matter and the difficulty to face some critical aspects that emerge from the analysis of some actual cases of contracts, in particular when the customer credit must be evaluated because of the early termination during the life of an installment contract (Van Horne 2002; Van Horne \& Wachowicz, 2009).

Building upon a Peccati's (1986) model, which separates three components of this debt at a given date, (outstanding debt, or capital share, and impairment reimbursement and penalty, or damage share), Migliavacca et al., $(2017,2015,2016)$ expand the discussion by extending the previous results. In particular, it is possible to demonstrate that the calculation and appraisal of those components turns out to be fruitful in two different contexts, namely both from the legal (lawsuit) and the financial accounting (and reporting) perspectives, in particular under some accounting methodologies (in-balance-sheet leases, such as by IFRS, and off-balance-sheet leases, such as by Italian GAAP).

In this paper, the authors propose a model for a precise quantification of the residual debt, the damage impairment and the penalty shares based on the contractual and implicit IRRs and on the market prime rate that is compatible with both finance and accounting perspective and, therefore, actual cases are studied within a multi-disciplinary framework.

Moreover, the model could be generalized taking into account also default interest rate and with the early termination of the contract closer or further to the maturity date of the lease agreement.

\section{Acknowledgments}

The authors are grateful to anonymous referees and to the participants of the $17^{\text {th }}$ Eurasian Businsess and Economic Society Conference, EBES 2015 in Venice (Italy) for comments which have improved the paper and led to this final version. This paper circulated as earlier drafts under the titles "A multi-disciplinary financial and accounting framework to outstanding debt assessment and default for lease agreement". This research was partially supported by MIUR (Ministero dell'Istruzione, dell'Università e della Ricerca scientifica), Italy.

\section{References}

Beattie, V., Goodacre, A., \& Thomson, S. J. (2006). International lease-accounting reform and economic consequences: The views of UK users and preparers. The International Journal of Accounting, 41(1), 
75-103. https://doi.org/10.1016/j.intacc.2005.12.003

Carretta, A., \& Nicolini, G. (2004). La valutazione del leasing nella fase di esecuzione del contratto: il calcolo dell'equo compenso e del risarcimento del danno [Leasing Evaluation in the execution of the contract: fair reimbursement and damage compensation]. Rivista dei Dottori Commercialisti, LV(3), 515-531.

Goodacre, A. (2003). Assessing the potential impact of lease accounting reform: A review of the empirical evidence. Journal of Property Research, 20(1), 49-66. https://doi.org/10.1080/0959991032000051962

Hull, J. C. (1982). The bargaining positions of the parties to a lease agreement. Financial Management, 11 (Autumn), 71-79. https://doi.org/10.2307/3665000

IFRS. (nd.). Accounting Principle IAS17, Pub. L. No. 17, International Financial Reporting Standards.

Imhoff, E. A., \& Thomas, J. K. (1988). Economic consequences of accounting standards: The lease disclosure rule change. Journal of Accounting and Economics, 10(4), 277-310. https://doi.org/10.1016/0165-4101(88)90006-7

Lease, R. C., McConnell, J. J., \& Schallheim, J. S. (1990). Realized returns and the default and prepayment experience of financial leasing contracts. Financial Management, 19, 11-20.

McConnell, J. J., \& Schallheim, J. S. (1983). Valuation of asset leasing contracts. Journal of Financial Economics, 12(2), 237-261.

McGregor, W. J. (1996). Accounting for leases: a new approach: recognition by lessees of assets and liabilities arising under lease contracts. Norwalk, CT: Financial Accounting Standards Board.

Migliavacca, A., Puddu, L., Tibiletti, L., \& Uberti, M. (2017). An Integrated Financial and Accounting Approach to Outstanding Debt Assessment for Lease Agreement. In Bilgin M., Danis H., Demir E., Can U. (Eds.), Country Experiences in Economic Development, Management and Entrepreneurship. Eurasian Studies in Business and Economics. https://link.springer.com/chapter/10.1007/978-3-319-46319-3_37

Migliavacca, A., Uberti, M., Puddu, L., \& Tibiletti, L. (2015). Controversy in contracts with installment plans: financial and accounting approaches to early termination assessments. In SGEM 2015 Conference Proceedings of 2nd International Multidisciplinary Scientific Conferences on Social Sciences and Arts. https://doi.org/10.5593/SGEMSOCIAL2015/B22/S6.012

Migliavacca, A., Uberti, M., Puddu, L., \& Tibiletti, L. (2016). A multi-disciplinary financial and accounting framework to outstanding debt assessment and default for lease agreement. In V. Cantino, P. De Vincentiis, G. Racca (Eds.), Risk management: perspectives and open issues. A multi-disciplinary approach (pp. 407-417). London: Mac Graw Hill Education.

Nicolini, G. (2004). La valutazione del leasing nella fase di esecuzione del contratto: principi, metodologie e casi concreti. [Leasing evaluation in the execution of the contract: principles, methodologies and case studies]. Bancaria, 60(4).

OIC. Accounting Principle OIC12, Pub. L. No. 12 (2014).

OIC. Accounting Principle OIC31, Pub. L. No. 31 (2014).

Peccati, L. (1986). Danno e penale in una clausola di risoluzione d'un contratto di leasing. [Damage and penalties in leasing contract termination clauses]. Rivista Italiana del Leasing, 2(1), 41-50.

Slovin, M. B., Sushka, M. E., \& Polonchek, J. A. (1990). Corporate Sale-and-Leasebacks and Shareholder Wealth. The journal of finance, 45(1), 289-299. https://doi.org/10.1111/j.1540-6261.1990.tb05094.x

Van Horne James, C. (2002). Financial Management \& Policy, 12/E. Pearson Education India.

Van Horne, J. C., \& Wachowicz, J. M. (2008). Fundamentals of financial management. Pearson Education.

Wilkins, T., \& Zimmer, I. (1983). The effect of leasing and different methods of accounting for leases on credit evaluations. The Accounting Review, 58(4), 749-764.

\section{Notes}

Note 1. The last installment refers to the asset's purchase price agreed to the subscription of the financial lease contract to be paid at the expiration $T$ for the exercise of this option.

Note 2. On a closer inspection, we can say that the $P$ amount is the maximum potential value of the penalty, because the question normally is brought up for its reduction. 


\section{Copyrights}

Copyright for this article is retained by the author(s), with first publication rights granted to the journal.

This is an open-access article distributed under the terms and conditions of the Creative Commons Attribution license (http://creativecommons.org/licenses/by/4.0/). 